\title{
Pemanfaatan Limbah Sampah Kota sebagai Kompos
}

\author{
Utilization of Municipal Waste as Compost \\ Sri Ngapiyatun", Arief Rahman, Humairo Aziza, Budi Winarni, Wartomo \\ Politeknik Pertanian Negeri Samarinda, Jl. Samratulangi PO BOX 192 Samarinda, Indonesia
}

${ }^{*}$ Corresponding Author: ngapiyatun.77@gmail.com

\begin{abstract}
ABSTRAK
Penelitian ini didasarkan pada upaya pemanfaatan limbah sampah kota yang keberadaannya melimpah dan mencemari lingkungan agar dapat dimanfaatkan menjadi suatu produk yang memiliki nilai ekonomis tinggi yaitu kompos, selain itu juga dapat menjadi solusi dalam mengatasi masalah kelangkaan serta mahalnya harga pupuk saat ini. Penelitian ini dilaksanakan di kampus Politeknik Pertanian Negeri Samarinda, dengan lamanya waktu penelitian adalah 3 bulan terhitung mulai bulan Juli sampai dengan Oktober 2020 yang meliputi: persiapan alat dan bahan, pembuatan kompos, pengambilan data dan analisis kompos. Tujuan penelitian yaitu mengetahui lama waktu pembuatan kompos hingga kompos dikatakan jadi, dan mengetahui kualitas kompos berdasarkan standar SNI 19-7030-2004. Hasil penelitian menunjukkan bahwa; kompos jadi pada hari ke-19 yang ditandai dengan warna kompos coklat kehitaman, tidak berbau, bentuk/tekstur remah dan suhunya sudah stabil mendekati suhu ruang dan kompos yang dihasilkan jika dibandingkan dengan standar SNI 19-7030-2004 untuk C organik, N dan K memenuhi standar sedangkan $\mathrm{pH} \mathrm{H} 2 \mathrm{O}, \mathrm{C} / \mathrm{N}$ rasio dan $\mathrm{P}$ belum memenuhi standar SNI 19-7030-2004.
\end{abstract}

Kata Kunci : limbah, sampah kota, kompos, standar SNI 10-7030-2004

\begin{abstract}
The research is based on the efforts to utilize municipal waste which is abundant and pollutes the environment so that it can be used as a product that has a high economic value, namely compost, besides that it can also be a solution in overcoming the problem of scarcity and the current high price of fertilizers. This research was conducted at the Samarinda State Agricultural Polytechnic campus, with a length of time is 3 months starting from July to October 2020 which includes: preparation of tools and materials, composting, data collection and compost analysis. The research objectives were to determine the length of time for making compost until the compost was said to be finished, and to determine the quality of the compost based on SNI 19-7030-2004 standards. The results showed that: (1) Finished compost on the 19th day which was marked with a blackish brown compost color, odorless, crumb shape / texture and the temperature was stable close to room temperature, and (2) the resulting compost when compared to SNI standards 19-7030-2004 for organic $C, N$ and $K$ meet the standards, while the $\mathrm{pH} H 2 \mathrm{O}, \mathrm{C} / \mathrm{N}$ ratio and $P$ have not met the SNI 19-7030-2004 standards.
\end{abstract}

Keywords : waste, municipal waste, compost, SNI 10-7030-2004 standards

\section{PENDAHULUAN}

Pencemaran lingkungan sebagian besar disebabkan oleh limbah organik yang tidak terurai dengan baik sehingga menimbulkan masalah-masalah lingkungan seperti bau, gas beracun, hama dan penyakit. Untuk menanggulangi masalah tersebut dibutuhkan biaya yang tidak sedikit termasuk didalamnya biaya pengolahan, transportasi, tenaga kerja, sarana dan prasarana (Indrapuri, 2007).

Berbagai cara dan upaya saat ini terus dilakukan dalam rangka meminimalisasi kerusakan lingkungan yang diakibatkan dari berbagai macam aktivitas manusia seperti cemaran limbah industri dari berbagai kegiatan industri atau cemaran limbah dari aktivitas kehidupan manusia sehari-hari berupa sampah (Isroi, 2008).

Produksi sampah di kota Samarinda mencapai $1.406 \mathrm{~m}^{3} /$ hari yang dihasilkan dari rumah tangga, industri, pasar, toko dan rumah sakit (Isroi, 2008). Sampah organik perkotaan yang merupakan bahan baku kompos berkisar $50-80 \%$ sampah kota (Indrapuri, 2007).

Pengomposan bukanlah suatu hal yang baru dan merupakan salah satu upaya pengolahan sampah dalam rangka mendaur ulang limbah organik dengan konsep 
pembusukan bahan organik melalui proses pelapukan, disamping tidak merusak dan ramah lingkungan. Masyarakat dapat membuat sendiri tidak memerlukan peralatan yang mahal, jika dikelola dengan baik maka akan menjadi suatu produk yang bernilai ekonomis dan sebagai alternatif terbaik dalam manajemen pengelolaan limbah organik (Indriani, 2002).

Penelitian ini bertujuan untuk mengetahui lama waktu pembuatan kompos hingga kompos dikatakan jadi, dan mengetahui kualitas kompos berdasarkan standar SNI 19-7030-2004. Hasil yang diharapkan dalam penelitian ini yaitu dapat memberikan informasi ke masyarakat luas bahwa limbah sampah kota dapat dimanfaatkan sebagai kompos dengan cara yang sederhana dan mudah dilakukan sehingga dapat mengatasi masalah pencemaran lingkungan.

\section{METODE PENELITIAN}

\section{A. Waktu dan Tempat Penelitian}

Penelitian ini dilaksanakan di kampus Politeknik Pertanian Negeri Samarinda, dengan lamanya waktu penelitian adalah 3 bulan terhitung mulai bulan Juli sampai dengan Oktober 2020 yang meliputi: persiapan alat dan bahan, pembuatan kompos, pengambilan data dan analisis kompos. Tujuan penelitian yaitu mengetahui lama waktu pembuatan kompos hingga kompos dikatakan jadi, dan mengetahui kualitas kompos berdasarkan standar SNI 19-7030-2004.

\section{B. Alat dan Bahan}

Alat yang digunakan adalah gelas piala, gelas ukur, parang, cangkul, skop, timbangan, alat tulis kantor, termometer dan kamera. Sedangkan bahan yang digunakan adalah limbah sampah kota, tisue, kertas label, dan terpal.

\section{Prosedur Penelitian}

\section{Bahan baku kompos}

Bahan baku kompos yaitu sampah kota dicacah menggunakan parang hingga halus menjadi ukuran kurang lebih $3 \mathrm{~cm}$ dengan tujuan supaya lebih capat terdekomposisi.

\section{Pembuatan kompos}

Bahan kompos berupa sampah kota ditambah dengan aktivator MOL dari limbah batang pisang, diaduk hingga merata dan ditambahkan air sampai kandungan mencapai $30 \%$ yang ditandai bila adonan dikepal dengan tangan, air tidak menetes dan bila kepalan dilepas, maka adonan masih tetap menggumpal. Kemudian adonan digundukkan diatas lantai/ubin dan ditutupi dengan terpal, dan ditempat yang terlindung dari sinar matahari dan hujan langsung.

Masa pengomposan dibatasi selama 30 hari, karena waktu 30 hari dianggap proses pengomposan sudah berlangsung sempurna.

\section{Pengamatan kompos}

Dilakukan pengamatan terhadap perubahan fisik kompos setiap hari yaitu: warna, bau, bentuk, suhu, dan hari keberapa kompos jadi, dan dibandingkan dengan bahan kompos (sampah kota) saat awal pengomposan.

\section{Analisis kompos}

Setelah kompos jadi, dilakukan analisis unsur hara kompos yang meliputi: $\mathrm{pH}, \mathrm{C} / \mathrm{N}$ rasio, $\mathrm{N}, \mathrm{P}$, dan $\mathrm{K}$ di laboratorium, dan dibandingkan dengan standar SNI 19-70302004, kemudian disajikan dalam bentuk tabel tabulasi perbandingan.

\section{HASIL DAN PEMBAHASAN}

\section{A. Hasil Analisis Fisik Kompos}

Dalam proses pengomposan selama 25 hari, dilakukan pengamatan sifat fisik kompos yang meliputi warna, bau, bentuk dan suhu kompos. Pengamatan tersebut dilakukan pada awal dan akhir proses pengomposan. Pengukuran terhadap suhu dilakukan setiap hari untuk mengetahui dinamika peningkatan suhu selama proses dekomposisi berlangsung hingga menjadi kompos. Hasil pengamatan terhadap kecepatan masa pengomposan yang diketahui dari lamanya bahan baku kompos berubah menjadi kompos yang siap untuk diaplikasikan. Hasil pengamatan terhadap kecepatan masa pengomposan ditabulasikan pada tabel 1 . 
Tabel 1. Kecepatan masa pengomposan

\begin{tabular}{|c|c|c|c|c|c|c|}
\hline \multirow{2}{*}{$\begin{array}{l}\text { Hari } \\
\text { ke- }\end{array}$} & \multicolumn{3}{|c|}{ Pengamatan } & \multicolumn{2}{|c|}{ Suhu $\left({ }^{\circ} \mathrm{C}\right)$} & \multirow[t]{2}{*}{ Keterangan } \\
\hline & Warna & Bau & Bentuk & Ruang & Kompos & \\
\hline 1 & Hijau segar & Tidak bau & Utuh & 28 & 28 & Belum jadi \\
\hline 2 & Hijau agak layu & Tidak bau & Utuh & 28 & 32 & Belum jadi \\
\hline 3 & Hijau agak layu & Agak bau & Utuh & 28 & 32 & Belum jadi \\
\hline 4 & Hijau layu & Agak bau & Utuh agak layu & 28 & 31,5 & Belum jadi \\
\hline 5 & Hijau layu & Berbau & Utuh agak layu & 28 & 31,5 & Belum jadi \\
\hline 6 & Hijau kekuningan & Berbau & Utuh agak layu & 28 & 31 & Belum jadi \\
\hline 7 & Hijau kekuningan & Berbau & Utuh layu & 28 & 31 & Belum jadi \\
\hline 8 & Kuning kecoklatan & Berbau & Mulai hancur & 28 & 31 & Belum jadi \\
\hline 9 & Kuning kecoklatan & Berbau & Mulai hancur & 28 & 31 & Belum jadi \\
\hline 10 & Kecoklatan & Berbau & Mulai hancur & 28 & 31 & Belum jadi \\
\hline 11 & Kecoklatan & Bau busuk & Agak hancur & 28 & 30 & Belum jadi \\
\hline 12 & Coklat & Bau busuk & Agak hancur & 28 & 29 & Agak jadi \\
\hline 13 & Coklat & $\begin{array}{l}\text { Bau agak } \\
\text { kurang }\end{array}$ & Agak hancur & 28 & 29 & Agak jadi \\
\hline 14 & Coklat agak hitam & $\begin{array}{l}\text { Bau agak } \\
\text { kurang }\end{array}$ & $\begin{array}{c}\text { Agak hancur } \\
\text { dan agak remah }\end{array}$ & 26,5 & 29 & Agak jadi \\
\hline 15 & Coklat agak hitam & $\begin{array}{l}\text { Bau agak } \\
\text { kurang }\end{array}$ & $\begin{array}{c}\text { Agak hancur } \\
\text { dan agak remah }\end{array}$ & 26,5 & 28,5 & Agak jadi \\
\hline 16 & $\begin{array}{c}\text { Coklat agak } \\
\text { kehitaman }\end{array}$ & $\begin{array}{c}\text { Bau kurang } \\
\text { bau }\end{array}$ & Agak remah & 26,5 & 28 & Mulai jadi \\
\hline 17 & Coklat kehitaman & Bau kurang & Agak remah & 28 & 29,5 & Mulai jadi \\
\hline 18 & Coklat kehitaman & Tidak Bau & Remah & 28 & 29,5 & Jadi \\
\hline 19 & Coklat kehitaman & Tidak bau & $\begin{array}{c}\text { Remah agak } \\
\text { lapuk }\end{array}$ & 28 & 28 & Jadi \\
\hline 20 & Coklat kehitaman & Tidak bau & $\begin{array}{c}\text { Remah agak } \\
\text { lapuk }\end{array}$ & 28 & 28 & Jadi \\
\hline 21 & Hitam kecoklatan & Tidak bau & $\begin{array}{c}\text { Ramah agak } \\
\text { lapuk }\end{array}$ & 28 & 28 & Jadi \\
\hline 22 & Hitam kecoklatan & Tidak bau & Lapuk & 28 & 28 & Jadi \\
\hline 23 & Hitam kecoklatan & Tidak bau & Lapuk & 28 & 28 & Jadi \\
\hline 24 & Hitam & Tidak bau & Lapuk & 28 & 28 & Jadi \\
\hline 25 & Hitam & Tidak bau & Lapuk & 28 & 28 & Jadi \\
\hline
\end{tabular}

Dari hasil penelitian pada Tabel 1 dapat dilihat bahwa kompos jadi atau matang terjadi pada hari ke-19 yang ditandai dengan warna kompos coklat kehitaman, tidak berbau, bentuk/teksturnya remah (hancur bila diremas) dan suhu kompos dalam ruangan tempat pengomposan berlangsung yang dapat dilihat pada Gambar 1 dan 2.

Pengomposan dilakukan selama 25 hari, secara visual kematangan kompos dapat diketahuai antara lain dari :

\section{Bau}

Pada awal proses pengomposan tercium bau tidak sedap dan setelah melalui proses dekomposisi, kompos yang sudah matang berbau seperti tanah. Hal ini diduga terhambatnya aerasi sehingga terjadi proses anaerob yang menghasilkan bau tidak sedap. Proses anaerob akan menghasilkan senyawa-senyawa yang berbau tidak sedap sseperti asam-asam organik, amonia dan $\mathrm{H}_{2} \mathrm{~S}$ (Indrapuri, 2007). Aerasi dapat ditingkatkan dengan melakukan pembalikan pada tumpukan kompos.

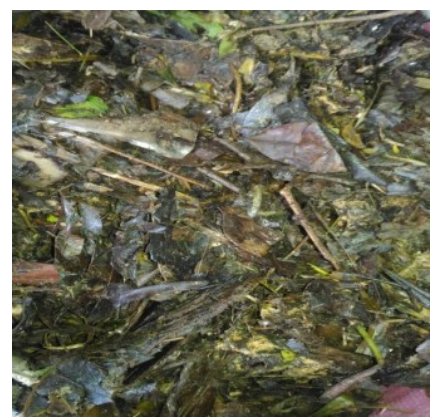


Gambar 1. Bahan kompos saat awal pengomposan

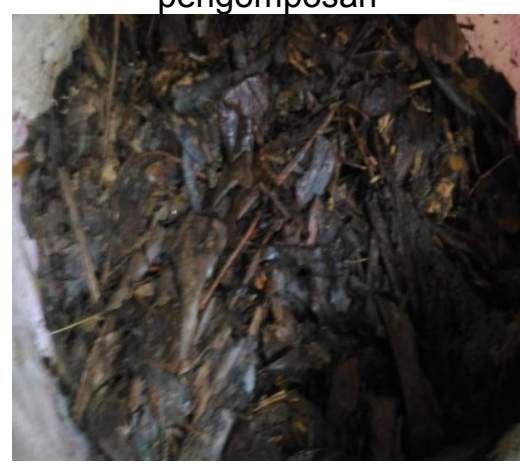

Gambar 2. Akhir pengomposan (kompos jadi)

\section{Warna}

Warna kompos yang sudah matang adalah berwarna coklat kehitaman (Gambar 2), perubahan warna dari sampah kota yang awalnya masih segar (kehijauan) pada awal pengomposan hingga coklat kehitaman pada akhir pengomposan disebabkan oleh terdekomposisinya bahan organik oleh aktivitas bermacam-macam mikroorganisme. Proses dekomposisi aerob ditunjukkan dengan terjadinya perubahan warna menjadi kehitaman (Isroi, 2008).

\section{Suhu}

Suhu kompos yang sudah matang mendekati suhu awal pengomposan atau suhu ruang pengomposan. Suhu meningkat pada awal pengomposan lebih dari $30^{\circ} \mathrm{C}$ dan tetap tinggi selama waktu tertentu. Menurut Isroi (2008), hal ini menunjukkan terjadinya proses dekomposisi/penguraian bahan organik yang sangat aktif. Mikroba-mikroba di dalam kompos dengan menggunakan oksigen akan menguraikan bahan organik menjadi $\mathrm{CO}_{2}$, uap air dan panas. Setelah sebagian besar bahan telah terurai maka suhu berangsur-angsur mengalami penurunan. Pada saat itu terjadi pematangan kompos yaitu pembentukan humus liat.

Menurut Indriani (2002) bahwa faktor suhu sangat berpengaruh terhadap proses pengomposan karena berhubungan dengan jenis mikroorganisme yang terlibat. Suhu optimum bagi pengomposan adalah $40-60^{\circ} \mathrm{C}$, dengan suhu maksimum $75^{\circ} \mathrm{C}$. Jika suhu pengomposan mencapai $40^{\circ} \mathrm{C}$, aktivitas mikroorganisme mesofil akan digantikan oleh mikroorganisme termofil. Jika suhu mencapai $60^{\circ} \mathrm{C}$, fungi akan berhenti bekerja dan proses perombakan dilanjutkan oleh actinomyces serta strain bakteri pembentuk spora.

4. Bentuk/ tekstur

Kompos yang telah matang bersifat remah, terasa lunak ketika dihancurkan, ketika diremas-remas mudah hancur dan terjadi penyusutan volume/bobot kompos seiring dengan kematangan kompos. Dalam penelitian ini volume kompos mengalami penyusutan, yang mana peenyusutannya sebanyak 20\%. Menurut Indriani (2002) bahwa bahan-bahan organik pada pembuatan kompos terjadi aneka perubahan hayati yang dilakukan oleh jasad-jasad renik, perubahan tersebut yaitu: (1) penguraian hidrat arang, selulos, hemiselulosa dan lainlain menjadi CO2 dan air, (2) penguraian zat lemak dan lilin mejadi CO2 dan air, (3) penguraian zat putih telur melalui amidaamida dan asam-asam amino menjadi amoniak, CO2 dan air, (4) terjadi pengikatan beberapa jenis unsur hara di dalam tubuh jasad-jasad renik terutama $N, P$ dan $K$, unsur-unsur ttersebut akan terlepas kembali bila jasad-jasad tersebut mati, dan (5) pembebasan unsur-unsur hara dari senyawasenyawa organik menjadi senyawa anorganik yang berguna bagi tanaman.

Dalam penelitian waktu yang diperlukan hingga kompos matang/jadi sekitar 19 hari dikarenakan bahan kompos berasal dari sampah kota yang terdiri dari beberapa jenis bahan organik dan relatif mudah lapuk sehingga proses pengomposan berjalan cepat. Menurut pendapat Sofian (2006), bahwa variasi bahan baku yang digunakan sangat berpengaruh yaitu makin bervariasi bahan baku yang digunakan dalam pembuatan kompos maka penguraiannya relatif lebih cepat dibandingkan bahan baku yang sejenis.

\section{B. Pengamatan kandungan unsur hara kompos}

Kompos hasil penelitian setelah jadi kemudian dianalisis kandungan unsur hara kompos yang meliputi: $\mathrm{pH}, \mathrm{C} / \mathrm{N}$ rasio, $\mathrm{N}, \mathrm{P}$, dan $\mathrm{K}$ di laboratorium, dan dibandingkan dengan standar SNI 19-7030-2004, kemudian disajikan dalam bentuk tabel tabulasi perbandingan. 
Tabel 2. Perbandingan kandungan unsur hara kompos dengan standar SNI 19-70302004

\begin{tabular}{|c|c|c|c|}
\hline Parameter & $\begin{array}{l}\text { Standar } \\
\text { SNI }\end{array}$ & $\begin{array}{c}\text { Kompos } \\
\text { Hasil } \\
\text { Penelitian }\end{array}$ & Keterangan \\
\hline $\mathrm{pH} \mathrm{H} 2 \mathrm{O}$ & $\begin{array}{l}6,80- \\
7,49\end{array}$ & 6,71 & $\begin{array}{c}\text { Belum } \\
\text { memenuhi } \\
\text { standar SNI }\end{array}$ \\
\hline C-Organik & $9,8-32$ & 25,55 & $\begin{array}{l}\text { Memenuhi } \\
\text { standar SNI }\end{array}$ \\
\hline $\mathrm{C} / \mathrm{N}$ rasio & $10-20$ & 28,71 & $\begin{array}{c}\text { Belum } \\
\text { memenuhi } \\
\text { standar SNI }\end{array}$ \\
\hline $\mathrm{N}$ & $>0,40$ & 0,89 & $\begin{array}{l}\text { Memenuhi } \\
\text { standar SNI }\end{array}$ \\
\hline$P$ & $>0,1$ & 0,09 & $\begin{array}{c}\text { Belum } \\
\text { memenuhi } \\
\text { standar SNI }\end{array}$ \\
\hline K & $>0,2$ & 0,56 & $\begin{array}{l}\text { Memenuhi } \\
\text { standar SNI }\end{array}$ \\
\hline
\end{tabular}

Berdasarkan Tabel 2 dapat dilihat bahwa kandungan hara kompos hasil penelitian jika dibandingkan dengan standar SNI 19-7030-2004 untuk pH H2O, C/N rasio dan $\mathrm{P}$ masih belum memenuhi standar, hal ini disebabkan karena bahan baku kompos yang digunakan murni dari sampah kota tanpa campuran bahan lain yang bisa menaikkan $\mathrm{pH}$ dan $\mathrm{P}$ dalam kompos. Dalam hal ini Sutedjo dan Kartaasapoetra (2002), menyatakan bahwa proses pengomposan akan meenyebabkan perubahan pada $\mathrm{pH}$ bahan itu sendiri sebagai contoh proses pelepasan asam secara temporer akan menurunkan $\mathrm{pH}$, sedangkan produksi ammonia dari senyawa-senyawa yang mengandung nitrogen akan meningkatkan $\mathrm{pH}$ pada fase-fase awal pengomposan. $\mathrm{pH}$ kompos hasil penelitian mendekati netral yaitu 6,71 hanya selisih nilai 0,09.

Salah satu kriteria kematangan kompos adalah $\mathrm{C} / \mathrm{N}$ rasio, kompos hasil penelitian memiliki nilai $\mathrm{C} / \mathrm{N}$ rasio 28,71 dan belum memenuhi standar SNI. Bila $\mathrm{C} / \mathrm{N}$ rasio kompos melebihi nilai 20 berarti kompos tersebut belum siap diaplikasikan ke tanaman digunakan sebagai pupuk karena kompos belum terdekomposisi sempurna, sehingga perlu waktu lebih lama guna proses dekomposisi yang akan dihasilkan kompos yang berkualitas dengan nilai $\mathrm{C} / \mathrm{N}$ rasio kurang dari 20.

Dari hasil penelitian diperoleh nilai $P$ yaitu belum memenuhi standar yaitu 0,09 yang mana standar kompos menurut SNI adalah lebih dari 0,2 , hal ini dipengaruhi oleh waktu proses pengomposan yang kurang lama sehingga dekomposisi tidak berjalan dengan maksimal.

Kompos hasil penelitian untuk $\mathrm{pH} \mathrm{H} 20$, $\mathrm{C} / \mathrm{N}$ rasio dan $\mathrm{P}$ jika dibandingkan dengan standar SNI belum memenuhi standar. Meskipun $\mathrm{pH}$ belum memenuhi standar namun masih dalam rentang netral, hal ini disebabkan karena bahan baku yang digunakan murni tanpa campuran bahan lain. Menurut Widyatmoko dan Sintorini (2002), menyatakan bahwa proses pengomposan akan menyebabkan perubahan pada $\mathrm{pH}$ bahan itu sendiri, $\mathrm{pH}$ kompos yang telah matang biasanya mendekati netral. Nilai $\mathrm{C} / \mathrm{N}$ rasio hasil penelitian belum memenuhi standar yaitu 28,71 , hal ini diduga waktu pengomposan kurang lama sehingga nilai $\mathrm{C} / \mathrm{N}$ rasio masih tinggi.

\section{KESIMPULAN DAN SARAN}

\section{A. Kesimpulan}

Hasil penelitian menunjukkan bahwa:

1. Kompos jadi pada hari ke-19 yang ditandai dengan warna kompos coklat kehitaman, tidak berbau, bentuk/tekstur remah dan suhunya sudah stabil mendekati suhu ruang. 2. Kompos yang dihasilkan jika dibandingkan dengan standar SNI 19-7030-2004 untuk C organik, $\mathrm{N}$ dan $\mathrm{K}$ memenuhi standar sedangkan $\mathrm{pH} \mathrm{H} 2 \mathrm{O}, \mathrm{C} / \mathrm{N}$ rasio dan $\mathrm{P}$ belum memenuhi standar SNI 19-7030-2004.

\section{B. Saran}

Perlu adanya penelitian lanjutan tentang campuran bahan baku kompos sehingga akan dihasilkan kompos yang berkualitas sesuai dengan standar SNI 19-7030-2004.

\section{UCAPAN TERIMA KASIH}

Penulis mengucapkan terima kasih kepada Politeknik Pertanian Negeri Samarinda yang telah memberikan bantuan dana penelitian dalam pelaksanaan Penelitian PDP Tahun 2020.

DAFTAR PUSTAKA 
Damanhuri dan Padmi. 2016. Pengelolaan Sampah Terpadu. Penerbit ITB, Bandung.

Indrapuri. 2007. Buat Pupuk atau Kompos Dengan Katalek. Produksi CV. Agri Medika Raharja, Bogor.

Isroi. 2008. Kompos. Makalah Balai Penelitian Bioteknologi Perkebunan Indonesia, Bogor.

Indriani. Y. H., 2002. Membuat Kompos Secara Kilat. Penebar Swadaya, Jakarta.

Murbandono, H.S., 2009. Membuat Kompos. Penebar Swadaya, Jakarta.
Salundik dan Simamora. 2008. Meningkatkan Kualitas Kompos. Penebar Swadaya, Jakarta.

Soeryoko, Hery. 2011. Kiat Pintar Memproduksi Kompos. Lily Publisher, Yogyakarta.

Sofian. 2006. Sukses membuat kompos Dari Sampah. PT. Agro Media Pustaka, Jakarta.

Sutedjo. M. M dan A.G Kartaasapoetra. 2002. Pengantar IImu Tanah Terbentuknya Tanah dan Tanah Pertanian. Rineka Cipta, Jakarta.

Widyatmoko, H. dan Sintorini. 2002. Menghindari, Mengolah dan menyingkirkan Sampah. Abdi Tandur, Jakarta. 